\title{
BMJ Open Safety of corticosteroids in young children with acute respiratory conditions: a systematic review and meta-analysis
}

Ricardo M Fernandes, ${ }^{1,2}$ Aireen Wingert, ${ }^{\oplus 3}$ Ben Vandermeer, ${ }^{3}$ Robin Featherstone, ${ }^{3}$ Samina Ali, ${ }^{\circ, 5}$ Amy C Plint, ${ }^{6}$ Antonia S Stang, ${ }^{7}$ Brian H Rowe, ${ }^{8,9}$ David W Johnson, ${ }^{10}$ Dominic Allain, ${ }^{4}$ Terry P Klassen, ${ }^{11}$ Lisa Hartling ${ }^{3,4}$

To cite: Fernandes RM, Wingert $A$, Vandermeer $B$, et al. Safety of corticosteroids in young children with acute respiratory conditions: a systematic review and meta-analysis. BMJ Open 2019;9:e028511. doi:10.1136/ bmjopen-2018-028511

- Prepublication history and additional material for this paper are available online. To view please visit the journal (http:// dx.doi.org/10.1136/bmjopen2018-028511).

Received 11 December 2018 Revised 24 June 2019 Accepted 3 July 2019
Check for updates

(C) Author(s) (or their employer(s)) 2019. Re-use permitted under CC BY-NC. No commercial re-use. See rights and permissions. Published by BMJ.

For numbered affiliations see end of article.

Correspondence to

Lisa Hartling;

hartling@ualberta.ca

\section{ABSTRACT}

Objective Adverse events (AEs) associated with shortterm corticosteroid use for respiratory conditions in young children.

Design Systematic review of primary studies.

Data sources Medline, Cochrane CENTRAL, Embase and regulatory agencies were searched September 2014; search was updated in 2017.

Eligibility criteria Children $<6$ years with acute respiratory condition, given inhaled (high-dose) or systemic corticosteroids up to 14 days.

Data extraction and synthesis One reviewer extracted with another reviewer verifying data. Study selection and methodological quality (McHarm scale) involved duplicate independent reviews. We extracted $\mathrm{AEs}$ reported by study authors and used a categorisation model by organ systems. Meta-analyses used Peto ORs (p0Rs) and DerSimonian Laird inverse variance method utilising Mantel-Haenszel Q statistic, with 95\% Cl. Subgroup analyses were conducted for respiratory condition and dose.

Results Eighty-five studies (11505 children) were included; 68 were randomised trials. Methodological quality was poor overall due to lack of assessment and inadequate reporting of AEs. Meta-analysis (six studies; $n=1373$ ) found fewer cases of vomiting comparing oral dexamethasone with prednisone (p0R $0.29,95 \% \mathrm{Cl}$ 0.17 to $0.48 ; l^{2}=0 \%$ ). The mean difference in changefrom-baseline height after one year between inhaled corticosteroid and placebo was $0.10 \mathrm{~cm}$ (two studies, $\mathrm{n}=268 ; 95 \% \mathrm{Cl}-0.47$ to 0.67 ). Results from five studies with heterogeneous interventions, comparators and measurements were not pooled; one study found a smaller mean change in height z-score with recurrent high-dose inhaled fluticasone over one year. No significant differences were found comparing systemic or inhaled corticosteroid with placebo, or between corticosteroids, for other AEs; Cls around estimates were often wide, due to small samples and few events.

Conclusions Evidence suggests that short-term highdose inhaled or systemic corticosteroids use is not associated with an increase in AEs across organ systems. Uncertainties remain, particularly for recurrent use and growth outcomes, due to low study quality, poor reporting and imprecision.
Strengths and limitations of this study

- Examined safety outcomes associated with shortterm corticosteroid use across multiple common acute respiratory conditions in young children.

- Broad range of adverse events (AEs) captured across organ systems.

- Inconsistent definitions, assessments and reporting of AEs.

- Extensive variation in corticosteroid formulations and dosages within and between studies.

- Did not examine long-term corticosteroid use (>14 days).

\section{INTRODUCTION}

Corticosteroids are the cornerstone of treatment for many common paediatric respiratory conditions including croup and asthma. $^{1-3}$ These conditions often result in presentation to urgent and emergency care settings, in otherwise healthy children. Previous studies examining corticosteroid use in chronic asthma have demonstrated the potential for short-term and long-term adverse events (AEs), particularly growth inhibition, bone disease and adrenal suppression. ${ }^{4-6}$ While corticosteroids have demonstrated effectiveness for the acute treatment of many respiratory indications, clinicians are faced with considerable uncertainty regarding short-term safety, particularly among the youngest children. ${ }^{1}$

Previous systematic reviews have examined corticosteroids in preschool or schoolaged asthma or wheezing ${ }^{48}$; however, most focused on efficacy and were restricted to randomised controlled trials (RCTs). These reviews also focused on a specific underlying condition, disease severity, or particular corticosteroid, and mostly for longer-term administration (eg, for recurrent, persistent or 
chronic asthma). Current guidance on systematic assessment of harms highlights the need to include data from observational studies when considering safety outcomes. ${ }^{9}$ As well, it has been suggested that it may be useful to have a wider view of the evidence across a number of similar indications. ${ }^{10}$ Recent knowledge synthesis approaches have studied specific safety outcomes across conditions to increase power, with the assumption that some safety outcomes are not confounded by condition. ${ }^{10}$ Such a comprehensive approach to knowledge synthesis in this area is critical to inform treatment decisions, reduce practice variation and optimise management of young children who seek care due to acute respiratory illness.

The goal of this study was to synthesise evidence regarding the safety of short course corticosteroid use in young children (<6years) with acute respiratory conditions.

\section{METHODS}

This review followed internationally recommended methods and standards for systematic reviews. ${ }^{11-13}$ An a priori protocol was developed (available from authors).

\section{Patient and public involvement}

Patients and/or the public were not involved in the design or conduct of this systematic review.

\section{Literature search}

Original database searches were conducted September 2014 in Ovid Medline, the Cochrane Central Register of Controlled Trials (CENTRAL) via Wiley Cochrane Library, and Ovid Embase. Additional sources included regulatory agency databases: Drugs@FDA, Health Canada's Drug Products Database and the European Medicines Agency's European Public Assessment Reports. Search strategies combined index terms and keywords for respiratory illnesses, children and drug classes identified in the Global Initiative for Asthma (GINA) ${ }^{14}$ guidelines. Study design filters were applied to limit results to RCTs and observational studies. Update searches were executed in Medline and CENTRAL in February 2016, and then again in July 2017. Detailed search strategies are in online supplementary file 1 .

\section{Eligibility criteria}

We included primary studies involving population $(\mathrm{P})$ : children up to sixyears old; intervention (I): treated with single or recurrent systemic (any dose) or high-dose inhaled (as defined by the GINA guidelines ${ }^{14}$ ) corticosteroids for up to 14 days; comparator $(\mathrm{C})$ : any comparator; outcome $(\mathrm{O})$ : any AE; timing $(\mathrm{T})$ : any timing; and, setting (S): any inpatient or outpatient setting providing care to children with an acute respiratory condition. See online supplementary file 2 for detailed eligibility criteria.

Given the lack of standardised terminology for safety, we gathered information on all potentially drug-related harm outcomes ${ }^{15}$ from studies including, but not limited to: adverse drug reactions, adverse drug events, medication errors, side effects and potential adverse drug events. For consistency, these outcomes are referred to in the manuscript as AEs. Studies that did not report or mention AEs were excluded. Due to resource constraints and mean age of the studies, no attempt was made to contact study authors if no harms were reported in the text, or when there was potentially missing data; such efforts are unlikely to yield additional data.

\section{Study selection}

Two reviewers independently screened the titles and abstracts of all records using a priori selection criteria. Full texts of potentially eligible studies were reviewed by two reviewers independently using a standard form. Disagreements were resolved through consensus or consultation with a third reviewer.

\section{Data extraction}

One reviewer extracted data using a structured form, with verification by a second reviewer. Data were extracted on study characteristics (design features), patient characteristics (age, sex, baseline characteristics), respiratory conditions, interventions (type, dose, duration, route of administration, timing, cointerventions, rescue medications), outcomes (types and timing), care setting, funding sources and results.

AEs were extracted as reported by study authors and categorised using a published model based on organ systems (see Results section). ${ }^{16}$ A panel of clinicians with specialties in paediatrics, emergency medicine, respiratory medicine and clinical pharmacology rated each $\mathrm{AE}$ in order of clinical severity independent of knowledge of the study results.

\section{Assessment of methodological quality}

Two reviewers independently assessed the methodological quality of studies using the McMaster Quality Assessment Scale for Harms (McHarm) ${ }^{17}$; disagreements were resolved through discussion.

\section{Data synthesis}

A comparative summary of AEs for studies with more than one treatment arm was presented to provide an overall picture of which interventions had a high risk of specific AEs. Risk differences were pooled using the DerSimonian Laird inverse variance random-effects method utilising the Mantel-Haenszel $Q$ statistic. Binary data were also pooled using the Peto ORs (pORs) fixed-effects method. ${ }^{18}$ Studies that reported at least one event in at least one treatment arm were included in the analysis of pORs and all comparative studies were used for analysis of RD. One $\mathrm{AE}$ (growth) was reported as a continuous outcome and data were pooled using a DerSimonian Laird inverse variance random effects method as a mean difference (MD; in $\mathrm{cm})$. The $\mathrm{I}^{2}$ statistic was presented to quantify the magnitude of statistical heterogeneity between studies; while the $\mathrm{I}^{2}$ has the potential to be misinterpreted, it is the standard in the field and we chose to present the statistic for 


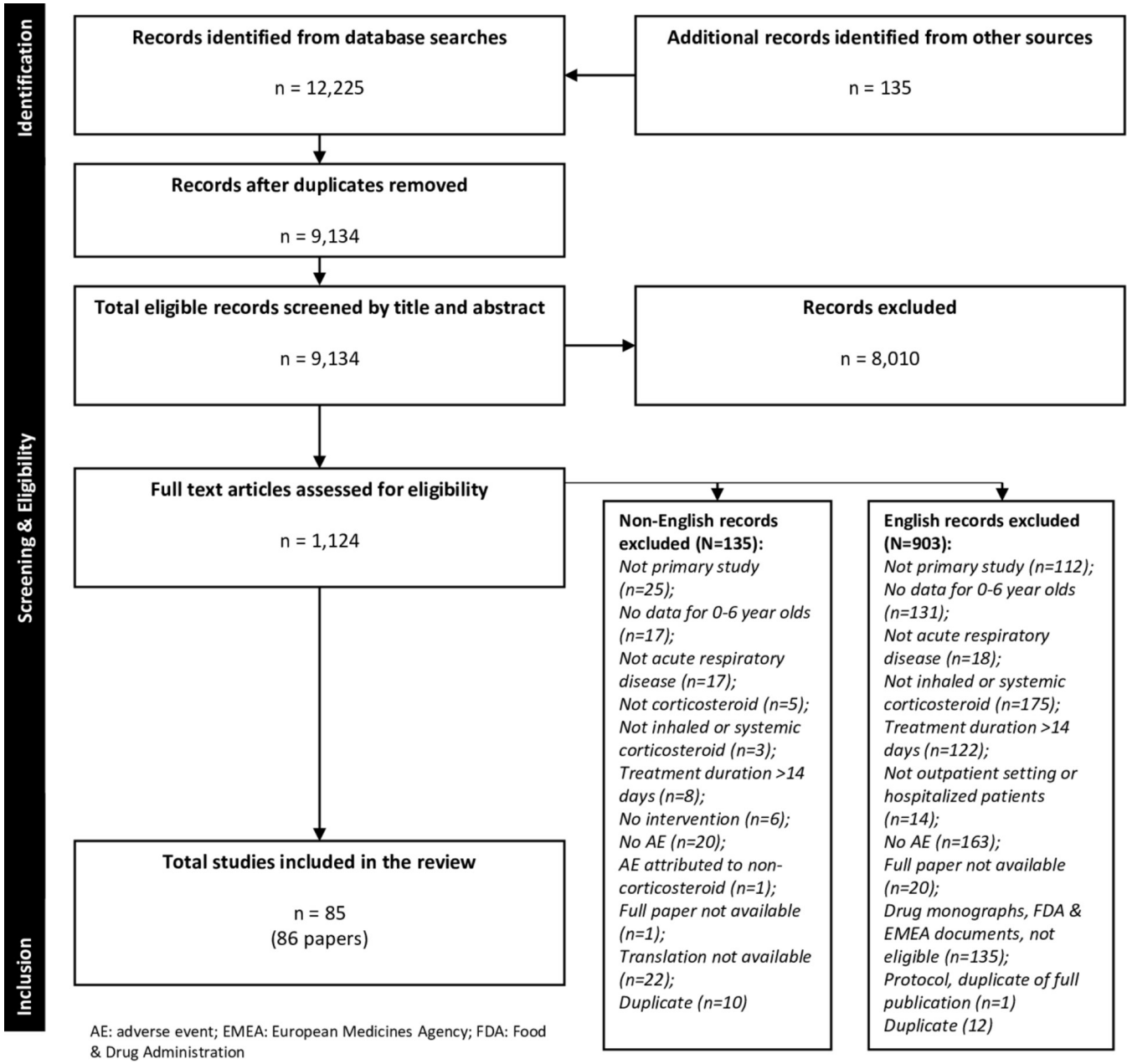

Figure 1 PRISMA study flow selection. PRISMA, Preferred Reporting Items for Systematic Reviews and Meta-Analyses.

informational purposes. ${ }^{19}$ Subgroup analyses from studylevel data were conducted for respiratory condition and dose (single vs multidose) using Cochran's $Q(\alpha=0.05)$ to detect statistical heterogeneity. Studies contributing no numerical data for analysis (eg, single arm studies, studies that reported no AEs overall) are summarised in online supplementary file 3. Assessment of small-study bias (for meta-analyses with at least eight studies) was planned using the funnel plot and Egger's test ${ }^{20}$; however, this was not conducted due to inadequate number of studies for each outcome. Analyses were conducted using Review Manager V.5.3 (Cochrane Collaboration) ${ }^{21}$ Graphs were constructed using TIBCO Spotfire S+Workbench V.3.4. ${ }^{22}$

\section{RESULTS}

Database and grey literature searches yielded 9134 records. Eighty-six papers $(85 \text { studies })^{23-108}$ involving 11505 participants were included (figure 1). Characteristics of the included studies are in online supplementary file 3. There was large variation in corticosteroid type, dose, duration and route of administration, both for systemic and inhaled corticosteroids. Methodological quality of studies was poor overall due to inadequate reporting of how AEs were defined and collected (table 1; online supplementary file 4).

\section{Adverse events}

Results below are presented according to the categories in table 2. Figures 2, 3 and 4 display forest plots of AEs comparing systemic corticosteroid to placebo, inhaled corticosteroid to placebo, and systemic dexamethasone to another systemic corticosteroid, respectively. Results of meta-analyses and subgroup analyses are in online supplementary file 5, with effect estimates and 95\% CIs. Forest plots from meta-analyses are in online supplementary file 6 . There was large variation in the number of studies and number of patients with available data for meta-analysis across comparisons and outcomes. Further, for four safety outcomes there were no events in both study arms (double-zero) across studies. In most cases, the subgroup analyses by dose and condition did not differ substantially from the overall results. Studies reporting no AEs overall are summarised in online supplementary file 7 .

\section{Infections and respiratory system}

The number of studies contributing to each meta-analysis ranged from one to seven (range 58-2178 children). 
Table 1 Summary of methodological quality assessments

\section{McHarm* criteria}

(1) Were the harms PRE-DEFINED using standardised or precise definitions?

(2) Were SERIOUS events precisely defined?

(3) Were SEVERE events precisely defined?

(4) Were the number of DEATHS in each study group specified OR were the reason(s) for not specifying them given?

(6) Was the mode of harms collection specified as PASSIVE?

(7) Did the study specify WHO collected the harms?

(8) Did the study specify the TRAINING or BACKGROUND of who ascertained the harms?

(9) Did the study specify the TIMING and FREQUENCY of collection of the harms?

(10) Did the author(s) use STANDARD scale(s) or checklist(s) for harms collection?

\begin{tabular}{|c|c|c|}
\hline & Unsure & $3(4)$ \\
\hline \multirow{3}{*}{$\begin{array}{l}\text { (11) Did the authors specify if the harms reported encompass ALL the events collected or a selected } \\
\text { SAMPLE? }\end{array}$} & Yes & 80 (94) \\
\hline & No & $2(2)$ \\
\hline & Unsure & $3(4)$ \\
\hline \multirow{3}{*}{$\begin{array}{l}\text { (12) Was the NUMBER of participants that withdrew or were lost to follow-up specified for each study } \\
\text { group? }\end{array}$} & Yes & $24(28)$ \\
\hline & No & $61(72)$ \\
\hline & Unsure & 0 \\
\hline \multirow[t]{3}{*}{ (13) Was the TOTAL NUMBER of participants affected by harms specified for each study arm? } & Yes & $16(19)$ \\
\hline & No & $69(81)$ \\
\hline & Unsure & 0 \\
\hline \multirow[t]{3}{*}{ (14) Did the author(s) specify the NUMBER for each TYPE of harmful event for each study group? } & Yes & $43(51)$ \\
\hline & No & $39(46)$ \\
\hline & Unsure & $3(4)$ \\
\hline \multirow[t]{3}{*}{ (15) Did the author(s) specify the type of analyses undertaken for harms data? } & Yes & $10(12)$ \\
\hline & No & 75 (88) \\
\hline & Unsure & 0 \\
\hline
\end{tabular}

${ }^{*}$ Methodological quality of publications/studies as assessed by the McHarm scale. ${ }^{17}$

†Sum of percentages may not total 100 due to rounding.

$(\%+)$

$6(7)$

79 (93)

0

2 (2)

$83(98)$

Unsure 0

Yes 0

No $\quad 85$ (100)

Unsure 0

Yes $10(12)$

No 75 (88)

Unsure 0

Yes $\quad 46(54)$

No $\quad 37(44)$

Unsure 2 (2)

Yes 11 (13)

No 73 (86)

Unsure 1 (1)

Yes $22(26)$

No $63(74)$

Unsure 0

Yes $20(24)$

No $\quad 65$ (76)

Unsure 0

Yes $\quad 39(46)$

No $\quad 45(53)$

Unsure 1 (1)

Yes $6(7)$

No 76 (89)

Unsure

$3(4)$

Yes $24(28)$

$61(72)$

Unsure 0

$69(81)$

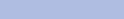

Unsure $\quad 3(4)$

Unsure

0

No of studies 
Table 2 Number of studies and participants reporting adverse events ${ }^{\star}$

\begin{tabular}{|c|c|c|c|c|}
\hline Organ system & $A E-$ category & AE-specific & No of studies & No of participants \\
\hline \multirow{26}{*}{$\begin{array}{l}\text { Infection and respiratory } \\
\text { Gl }\end{array}$} & Severe infections & & 5 & 1235 \\
\hline & (1) & Sepsis & 1 & 32 \\
\hline & (2) & Superinfection & 2 & 354 \\
\hline & (4) & Streptococcal infection & 1 & 129 \\
\hline & Systemic infections & & 5 & 1635 \\
\hline & (3) & Varicella & 3 & 1449 \\
\hline & Lung/trachea & & 10 & 2053 \\
\hline & (1) & Empyema & 1 & 600 \\
\hline & (2) & Pneumonia & 8 & 2051 \\
\hline & (3) & Respiratory distress & 2 & 2 \\
\hline & (3) & Croup & 2 & 131 \\
\hline & (4) & Viral parotitis & 1 & 27 \\
\hline & (5) & Pharyngitis & 1 & 129 \\
\hline & (6) & Persistent cough & 1 & 27 \\
\hline & (7) & Oral thrush & 3 & 837 \\
\hline & (8) & Otitis media & 4 & 1173 \\
\hline & (9) & Ear, nose, throat infection & 3 & 862 \\
\hline & (10) & Nasal discharge & 1 & 720 \\
\hline & (11) & Eye discharge & 1 & 720 \\
\hline & Voice complaints & & 5 & 794 \\
\hline & (2) & Nausea & 6 & 586 \\
\hline & (3) & Palatability & 3 & 170 \\
\hline & Abdominal pain & & 5 & 1332 \\
\hline & Diarrhoea & & 8 & 1346 \\
\hline & (1) & Diarrhoea & 7 & 1217 \\
\hline & (2) & Gastroenteritis & 1 & 129 \\
\hline \multirow[t]{12}{*}{ CNS and behaviour } & Tremor/jitteriness & & 8 & 1274 \\
\hline & (1) & Tremor & 7 & 1226 \\
\hline & (2) & Jittery & 1 & 48 \\
\hline & Behaviour change & & 14 & 2078 \\
\hline & (1) & Violent behaviour & 1 & 198 \\
\hline & (2) & Mood change & 7 & 1430 \\
\hline & (3) & Hyperactivity & 2 & 268 \\
\hline & (4) & Restlessness & 3 & 297 \\
\hline & (5) & New sleep problems & 3 & 408 \\
\hline & (6) & Emotional distress due to nebulizer mask & 1 & 82 \\
\hline & (7) & Psychosis & 1 & 1 \\
\hline & Headache & & 3 & 291 \\
\hline
\end{tabular}

Continued 


\begin{tabular}{|c|c|c|c|c|}
\hline Organ system & AE-category & AE-specific & No of studies & No of participants \\
\hline \multirow{8}{*}{ Dermatological } & Burn & & 1 & 198 \\
\hline & (1) & Hives & 2 & 199 \\
\hline & (2) & Rash & 8 & 1954 \\
\hline & (3) & Eczema & 1 & 129 \\
\hline & (5) & Tongue irritation & 1 & 82 \\
\hline & (6) & Positive weal & 1 & 1 \\
\hline & (7) & Bleeding from ear & 1 & 720 \\
\hline & Phlebitis & & 1 & 32 \\
\hline \multirow{5}{*}{$\begin{array}{l}\text { Endocrine/metabolic and } \\
\text { musculoskeletal }\end{array}$} & Fluid and electrolyte abnormalities & & 7 & 1849 \\
\hline & (5) & Dehydration & 1 & 720 \\
\hline & Growth & & 6 & 731 \\
\hline & Adrenal suppression & & 5 & 249 \\
\hline & Bone health & & 5 & 579 \\
\hline \multirow[t]{5}{*}{ Cardiovascular } & Arrhythmia & & 3 & 312 \\
\hline & (1) & Tachycardia & 2 & 178 \\
\hline & (2) & Palpitations & 1 & 134 \\
\hline & Hypertension & & 5 & 1491 \\
\hline & Congestive heart failure & & 1 & 50 \\
\hline General & General complaints & & 5 & 1146 \\
\hline & (1) & Immunosuppression & 3 & 146 \\
\hline & (2) & Tumour cell proliferation & 1 & 1 \\
\hline
\end{tabular}

*Each adverse event was clustered into its related organ system; a panel of clinicians ranked each AE category and its corresponding adverse events in order of clinical significance/severity. The organ systems are presented in order of frequency of reporting, beginning with the most frequently reported (ie, infection and respiratory). AE, adverse event; CNS, central nervous system; GI, gastrointestinal; URT, upper respiratory tract.

There were no statistically significant differences between: (1) systemic corticosteroid compared with placebo for severe infections, ${ }^{30} 749699$ systemic infections, ${ }^{30404383}$ infections of the lung/trachea 304054749698105 and the upper respiratory tract, ${ }^{30435465674}$ and voice complaints ${ }^{43}$ (estimated pORs between 0.15 and 1.26) and (2) inhaled corticosteroid compared with placebo for severe infections, ${ }^{45}$ systemic infections, ${ }^{43}{ }^{45} \mathrm{lung} /$ trachea,${ }^{45}$ infections of the upper respiratory tract ${ }^{37444565-67}$ or voice complaints ${ }^{3743100101}$ (estimated pORs between 0.54 and 1.51). No study comparing dexamethasone with another corticosteroid reported infections or respiratory AEs.

\section{Gastrointestinal tract}

The number of studies contributing to each meta-analysis ranged from one to seven (range 97-3176 children). There were no statistically significant differences between:
(1) systemic corticosteroid and placebo for gastrointestinal (GI) bleeding, ${ }^{30} 3240658387105$ vomiting, ${ }^{30} 384042708183$ abdominal pain ${ }^{30}$ or diarrhoea ${ }^{42} 77105$ and (2) inhaled corticosteroid and placebo for GI bleeding, ${ }^{65}$ vomiting 37456985101 or diarrhoea. ${ }^{37}$ Estimated pORs for both comparisons ranged from 0.89 to 1.10 .

Meta-analysis of six studies (1373 children) 252741495280 found fewer cases of vomiting in patients who received dexamethasone compared with another corticosteroid, although the number of events was small (12/663 vs $51 / 710$ cases; pOR $0.29,95 \%$ CI 0.17 to $\left.0.48 ; \mathrm{I}^{2}=0 \%\right)$. These studies focused on asthma (n=3), ${ }^{27} 4180$ croup $(n=2){ }^{49} 52$ or both $(\mathrm{n}=1)^{25}$; all compared oral dexamethasone with oral prednisone. No statistically significant difference was found for abdominal pain between dexamethasone and another corticosteroid. $^{25} 2752$ 


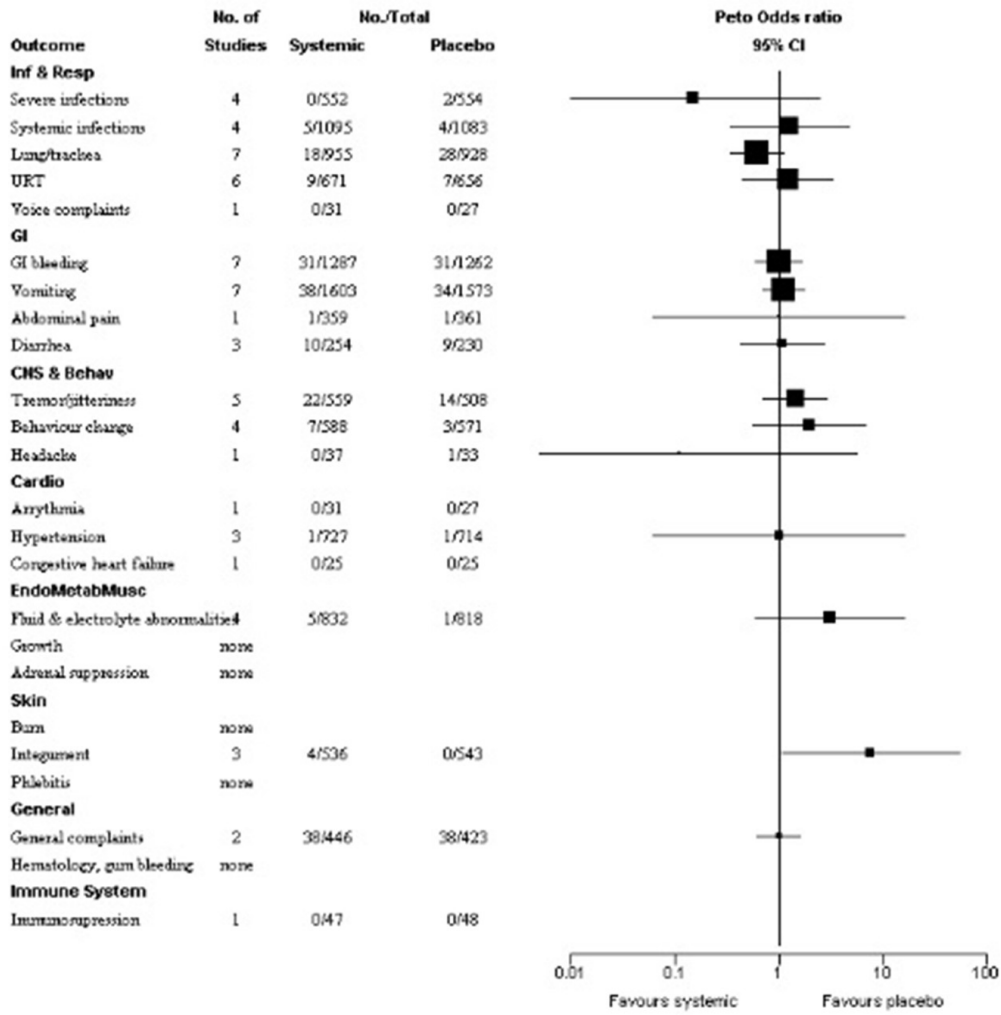

\begin{tabular}{|c|c|}
\hline $\begin{array}{c}\text { Peto Odds ratio } \\
95 \% \mathrm{Cl}\end{array}$ & $1^{2}$ \\
\hline $0.15(0.01,2.45)$ & 0 \\
\hline $1.26(0.34,4.68)$ & NA \\
\hline $0.61(0.34,1.12)$ & 0 \\
\hline $1.21(0.44,3.33)$ & 0 \\
\hline is & Na \\
\hline $1.00(0.60,167)$ & 0 \\
\hline $1.10(0.69,1.36)$ & 13 \\
\hline $1.01(0.05,16.11)$ & NA \\
\hline $1.09(0.43,2.73)$ & 0 \\
\hline $1.44(0.71,292)$ & 0 \\
\hline $1.95(055,692)$ & 0 \\
\hline $0.11(0.00,5.68)$ & ma \\
\hline $\mathrm{Nh}$ & NA \\
\hline $1.00(0.05,1599)$ & so \\
\hline $\mathrm{Nh}$ & NA \\
\hline $3.08(0.60,1594)$ & 0 \\
\hline $3.59(100,5401)$ & 0 \\
\hline $1.00(0.62,160)$ & 0 \\
\hline NA & NA \\
\hline
\end{tabular}

Figure 2 Forest plot of adverse events-systemic versus placebo.

\begin{tabular}{|c|c|c|c|}
\hline \multirow[b]{2}{*}{ Outcome } & \multirow{2}{*}{$\begin{array}{l}\text { Mo. of } \\
\text { Studies }\end{array}$} & \multicolumn{2}{|c|}{ No.JTotal } \\
\hline & & Inhaled & Placebo \\
\hline \multicolumn{4}{|l|}{ Inf \& Resp } \\
\hline Sevore irfoctionc & 1 & 2.62 & $4 / 67$ \\
\hline Systomic infoctions & 2 & $18 / 91$ & 20194 \\
\hline Lueftackes & 1 & 13.62 & $10 / 67$ \\
\hline UKT & 6 & 24495 & $24 / 499$ \\
\hline Poxe complaints & 4 & $38 / 343$ & $43 / 337$ \\
\hline \multicolumn{4}{|l|}{ GI } \\
\hline Gl Bloodive & 1 & 0,48 & 0/49 \\
\hline Ponutive & $s$ & 28,421 & $28 / 420$ \\
\hline Abdomiral pain & mom & & \\
\hline Distrites & 2 & $41 / 326$ & $46 / 328$ \\
\hline \multicolumn{4}{|l|}{ Skin } \\
\hline Bur & 1 & $0 / 27$ & $1 / 27$ \\
\hline Integument & 4 & 24,432 & $27 / 436$ \\
\hline Abdoniral pain & more & & \\
\hline \multicolumn{4}{|l|}{ EndoMctobMusc } \\
\hline Frid \& ebetrolyts dbsorms & mon & & \\
\hline Adrencl suppression. & 1 & 5.6 & $4 / 10$ \\
\hline \multicolumn{4}{|l|}{ Cus \& Behav } \\
\hline Tromorljittorinass & now & & \\
\hline Bohaviour charge & 3 & $6 / 134$ & $7 / 35$ \\
\hline Ho adectes & now & & \\
\hline \multicolumn{4}{|l|}{ Cardio } \\
\hline Anythmia & 1 & $0 / 29$ & $0 / 27$ \\
\hline Hypertension & non & & \\
\hline Congestive haut filluse & nom & & \\
\hline \multicolumn{4}{|l|}{ General } \\
\hline Geners consplaints & nom & & \\
\hline Hematoloeg, sum blosdive & now & & \\
\hline \multicolumn{4}{|l|}{ Immune System } \\
\hline Imumorupression & mom & & \\
\hline
\end{tabular}

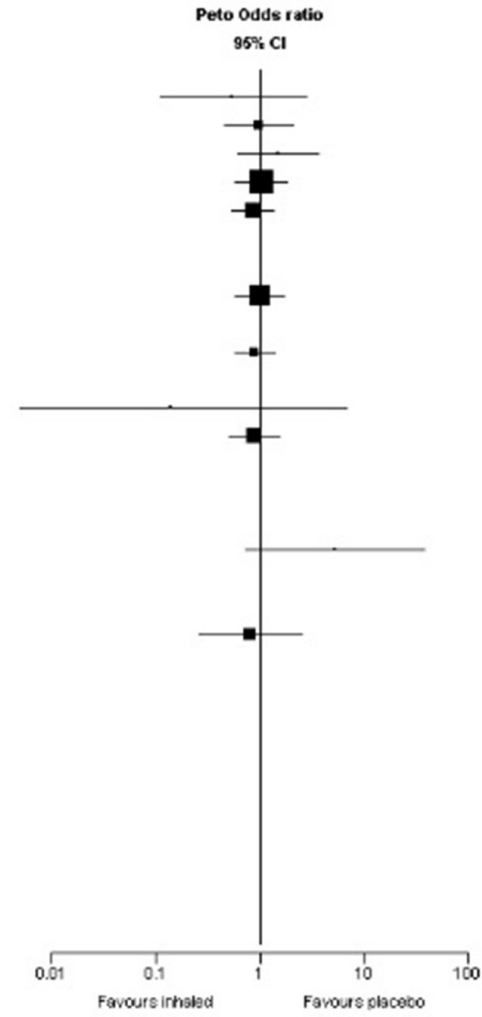

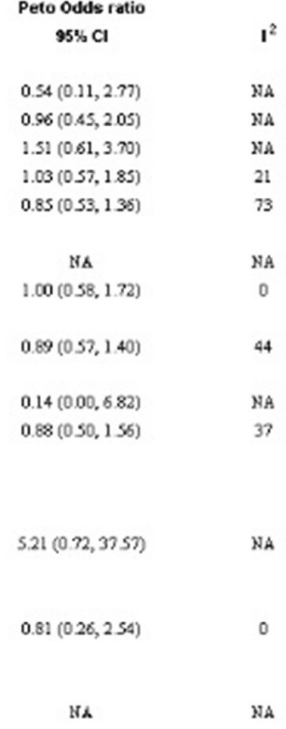

Figure 3 Forest plot of adverse events-inhaled versus placebo. 


\begin{tabular}{|c|c|c|c|}
\hline \multirow[b]{2}{*}{ Outcome } & \multirow{2}{*}{$\begin{array}{l}\text { Mo. of } \\
\text { Studies }\end{array}$} & \multicolumn{2}{|c|}{ No $-\mathcal{T}$ otal } \\
\hline & & examethasone & Other \\
\hline \multicolumn{4}{|l|}{ Ga } \\
\hline Gl bleedixe & mon & & \\
\hline Yonuitine & 6 & 12,663 & $\sin 10$ \\
\hline Abdominal pain. & 3 & 29188 & $48 / 254$ \\
\hline Dimmà & $n o m$ & & \\
\hline \multicolumn{4}{|l|}{ Cus \& Behav } \\
\hline Toumorifittoriness & 1 & 146 & $0 / 41$ \\
\hline Behaviour eharen & 2 & 35.60 & 38157 \\
\hline Hoxlacke & 2 & 71102 & $4 / 95$ \\
\hline \multicolumn{4}{|l|}{ General } \\
\hline General complaints & 2 & $3 / 102$ & 305 \\
\hline Hemstolocy, oum bleedire & none & & \\
\hline \multicolumn{4}{|l|}{ Cardio } \\
\hline Anythmis & 1 & 0/SS & $0 / 54$ \\
\hline Hypertenvion & 1 & 0/15 & $0 / 17$ \\
\hline Congestivo hast fallus & nom & & \\
\hline \multicolumn{4}{|l|}{ EndoMetabMusc } \\
\hline Fuid \& eleetrolyte abroms & 1 & 193 & $2 / 15$ \\
\hline Growth & $\mathrm{mom}$ & & \\
\hline Adrenal rupsreyson. & none & & \\
\hline \multicolumn{4}{|l|}{ Skin } \\
\hline Bem & nom & & \\
\hline Intogumont & $n=m$ & & \\
\hline Plebbitis & 1 & 0/15 & $0 / 17$ \\
\hline \multicolumn{4}{|l|}{ Inf \& Resp } \\
\hline Severe infetions & $m=m$ & & \\
\hline Systemie infections & norn & & \\
\hline Laneltustes: & more & & \\
\hline UKT & mom & & \\
\hline Poxe complaints & mone & & \\
\hline \multicolumn{4}{|l|}{ Immune System } \\
\hline Immenorupsression & nom & & \\
\hline
\end{tabular}
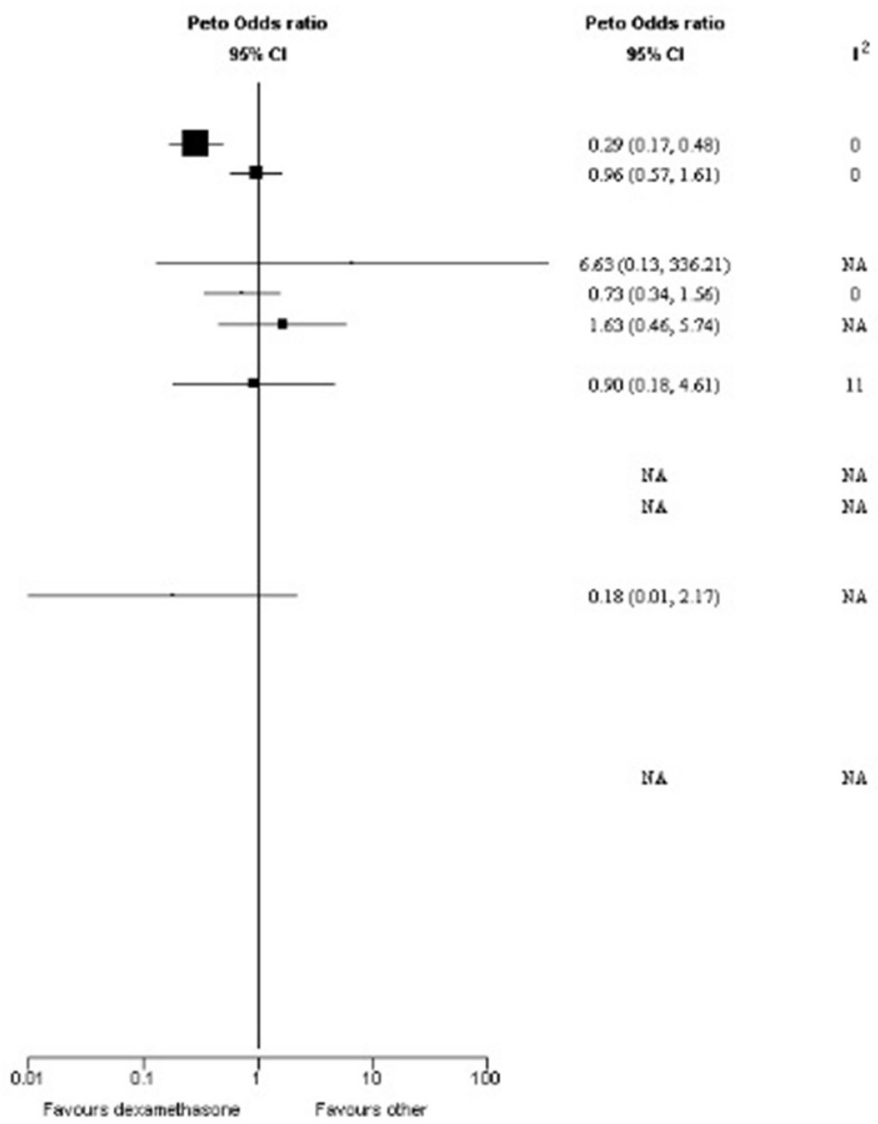

Figure 4 Forest plot of adverse events-dexamethasone versus other.

\section{CNS and behaviour effects}

The number of studies for each meta-analysis ranged from one to five (range 70-1159 children). The estimated pORs for the systemic corticosteroid and placebo were 1.44 for tremor/jitteriness, ${ }^{38} 557077831.95$ for behaviour change $^{30426777}$ and 0.11 for headache, ${ }^{38}$ with no statistically significant differences. There were also no differences between inhaled corticosteroid and placebo for behaviour change ${ }^{6785101}$; and dexamethasone and another corticosteroid for behaviour change,$^{5257}$ headache ${ }^{2752}$ or tremor/jitteriness, ${ }^{52}$ the latter with an estimated pOR of 6.63 from a small study $(\mathrm{n}=87)$ with only one reported event.

\section{Dermatologic conditions}

The number of studies per meta-analysis ranged from one to four (range 32-1079 children). There were no statistically significant differences between: (1) systemic corticosteroid and placebo for rash and hives ${ }^{30}{ }^{42} 67$ albeit with an estimated pOR of 7.59 (4/536 vs $0 / 543$; $95 \%$ CI 1.07 to 54.01) and (2) inhaled corticosteroid and placebo for rash, ${ }^{37} 4585$ hives $^{67}$ and burning sensation ${ }^{68}$ (estimated pORs 0.88 and 0.14 , respectively). No events of phlebitis were reported comparing dexamethasone to another corticosteroid. ${ }^{57}$

\section{Endocrine/metabolic and musculoskeletal systems}

There were no statistically significant differences for electrolyte abnormalities between systemic corticosteroid and placebo (estimated pOR 3.08) 304783102 and dexamethasone to another corticosteroid (estimated pOR 0.18). ${ }^{102}$

Pooled data for linear growth between inhaled corticosteroid and placebo included two studies $(\mathrm{n}=263)$ using recurrent doses for acute wheeze with follow-up at oneyear. ${ }^{28}{ }^{45}$ The estimated change-from-baseline height was small (MD $0.10 \mathrm{~cm}$; $95 \%$ CI -0.47 to 0.67 ; $\mathrm{I}^{2}=9 \%$ ). Five studies reported measurements of growth (height and weight) ranging from one to threeyears of follow-up, which could not be pooled due to heterogeneous interventions, comparators or outcome measurements. ${ }^{29} 31455871$ Three studies included data on inhaled corticosteroid versus placebo. One RCT on asthma ${ }^{58}$ $(n=20)$ comparing budesonide and placebo found no signs of growth retardation by height measurements at 12 months or after up to six treatments. An RCT of episodic wheeze ${ }^{29}(n=294)$ found height at threeyears of age was unaffected in children receiving budesonide or placebo. One RCT of inhaled fluticasone propionate at very high doses $(1500 \mu \mathrm{g}$ per day during upper respiratory infections) versus placebo in recurrent wheeze ${ }^{45}$ reported additional outcome data on height that was not pooled in the meta-analysis mentioned above. There was a smaller mean change in height $\mathrm{z}$ score in the corticosteroid group over one year (MD $-0.24 ; 95 \%$ CI -0.40 to -0.08 ; adjusted results).$^{45}$ Furthermore, mean weight was significantly lower at one-year follow-up in the fluticasone group $(\mathrm{n}=62)$ versus placebo $(\mathrm{n}=67)$; two children given 
fluticasone and one given placebo met criteria for 'failure to thrive' ${ }^{45}$ Finally, two small trials did not report group differences for other comparisons: total and mean height growth (at 8-19 months) for intravenous dexamethasone versus inhaled budesonide in asthma $(n=18)^{71}$; weight and height gains at 2 years for theophylline and metaproterenol with or without systemic prednisone on prevention of wheeze during upper respiratory infections in asthma $(\mathrm{n}=32){ }^{31}$

Five studies reported on adrenal function/suppression, with few children contributing data for this outcome. ${ }^{45} 57587189$ The RCT of high-dose inhaled fluticasone propionate versus placebo $\left(99\right.$ children with data) ${ }^{45}$ found no significant differences between groups in basal cortisol (baseline and 12 months). Another RCT in asthma reported no differences in serum cortisol and urinary cortisol/creatinine after 10 days of inhaled budesonide or placebo (16 children with data). A subgroup who received oral betamethasone $(n=9)$ showed significant changes from baseline after three days, but no differences at 12-14 days. ${ }^{58}$ Two studies included comparisons between different corticosteroids. One $\mathrm{RCT}^{89}$ in acute asthma compared intravenous prednisolone $(n=20)$ with nebulised budesonide $(\mathrm{n}=30)$ and found significant levels of suppressed serum cortisol in the prednisolone group, although not considered pathologic by the study authors. Although another RCT ${ }^{57}$ comparing intramuscular dexamethasone with oral prednisone for asthma $(n=32)$ found lower median urinary cortisol/creatinine in the former group at day 14 , there was no statistically significant difference. An $\mathrm{RCT}^{71}$ comparing intravenous dexamethasone $(n=9)$ with inhaled budesonide $(n=9)$ found no significant differences between groups from baseline for blood pressure and blood glucose measurements.

Five studies reported on bone health biomarkers, three of which compared inhaled corticosteroids and placebo; no pooled analyses were performed. ${ }^{2945} 586192$ One RCT ${ }^{29}$ compared inhaled budesonide $(\mathrm{n}=294)$ with placebo in episodic wheeze and found no effect on bone mineral density over three years. The RCT comparing high-dose inhaled fluticasone propionate with placebo $(n=59$ children with data) in viral wheeze ${ }^{45}$ reported no statistically significant differences between groups in lumbar bone mineral density, bone mineral content or bone age at 12 months. A small RCT ${ }^{58}$ comparing inhaled budesonide with placebo $(n=20)$ in asthma found transient decreased levels of bone and collagen markers post-treatment and in a subset of children who received oral betamethasone, with no difference between groups. A study of patients with acute respiratory illness ${ }^{92}$ compared hydrocortisone $(n=28)$, methylprednisone $(n=21)$ and controls $(n=51)$ and found decreased levels of osteocalcin and alkaline phosphatase in younger children 2 days post-treatment; these effects were reversed 12 days after treatment. A non-randomised controlled trial of 36 asthma patients ${ }^{61}$ compared intravenous methylprednisolone of three different durations and found that all had decreasing levels of serum osteocalcin that correlated with increasing duration of treatment.

\section{Cardiovascular system}

No significant differences were found between systemic corticosteroid and placebo in three bronchiolitis studies reporting hypertension (estimated pOR 1). ${ }^{32} 4083$ Single studies with up to 110 children did not report events for arrhythmia $^{43}$ and congestive heart failure ${ }^{47}$ (systemic or inhaled corticosteroid vs placebo); and arrhythmia ${ }^{27}$ or hypertension $^{57}$ (dexamethasone with another corticosteroid).

\section{General AEs/other symptoms}

Meta-analyses included a total of two studies (range 197-869 children). There were no statistically significant differences between: (1) systemic corticosteroid and placebo for pallor ${ }^{70}$ and (2) dexamethasone and another corticosteroid for dizziness ${ }^{52}$ or excessive urination. ${ }^{27}$ No study comparing inhaled corticosteroid with placebo reported general AEs.

\section{Immune system and oncology}

One study (95 participants) ${ }^{39}$ compared systemic corticosteroid and placebo and found no occurrences of immunosuppression. No other study reported immune system-related AEs.

\section{DISCUSSION}

This systematic review of studies in which short-course corticosteroids were administered to children under six years of age for acute respiratory conditions, included 85 studies involving more than 11000 patients. These studies used a variety of delivery routes, doses, formulations and duration of corticosteroids. Overall, the evidence suggests that short-term corticosteroid use is not associated with a significant increase in AEs across organ systems. However, given the low quality of included studies, the heterogeneous and poor reporting of AEs, and the lack of precision of results, considerable uncertainties remain regarding the safety of high-dose inhaled or systemic corticosteroids for these indications in this age range.

A common concern when using corticosteroids in young children is effect on growth. Results from a single, small trial $(n=129)$ of recurrent high-dose inhaled fluticasone propionate in wheezing preschoolers were heterogeneous across outcome measures, but suggested a small significant risk of growth suppression. ${ }^{45}$ Observational data have also suggested that multiple corticosteroid bursts can increase the risk of growth suppression, fractures, bone mineral accretion and osteopenia in children with underlying respiratory disease. ${ }^{56109}$ Conversely, a pooled analysis using change-from-baseline linear growth did not find significant differences, although the other included study used a substantially lower equivalent dose of inhaled corticosteroid. ${ }^{110}$ Further, results from individual studies reporting transient differences in bone 
and adrenal biomarkers are of unclear clinical relevance, particularly for previously healthy children and single use. This calls for caution and monitoring of linear growth, particularly when use of high-dose inhaled or systemic corticosteroid is recurrent.

We found no other statistically significant differences between systemic or inhaled corticosteroid and placebo, or between dexamethasone and other systemic corticosteroid, including subgroup analyses by respiratory condition or dose, for AEs across organ systems. Due to small sample sizes and low number of events, these results should be interpreted with caution. While we found increased pORs when comparing systemic corticosteroids for behavioural outcomes such as tremor/jitteriness and behaviour change, there were wide CIs around estimates. No study examined neurodevelopmental outcomes after corticosteroid administration; ideally, studies should assess children for potentially related long-term AEs using validated instruments in this domain. Results from case series and case reports added anecdotal evidence of rare cases of hypersensitivity, infection or behavioural AEs, which have been described. ${ }^{111} 112$ While the estimated increased $\mathrm{pOR}$ for rash and hives was close to statistical significance, no other differences were found in systemic or severe infections as well as immunosuppression.

This review did not ascertain a clear safety advantage between systemic or inhaled corticosteroids compared with placebo. When comparing between different systemic corticosteroids, evidence favoured oral dexamethasone over oral prednisone for vomiting (pOR 0.029; $95 \%$ CI 0.17 to $0.48 ; \mathrm{I}^{2}=0 \%$ ). Differences in palatability and tolerability between corticosteroids are well known to parents, healthcare providers and researchers, and can influence adherence to medication in children. ${ }^{113}$ Further, different specific formulations of corticosteroid (eg, prednisolone tablets vs prednisolone syrup) have been shown to influence taste and vomiting. ${ }^{25}$ However, cost and access to better tolerated formulations may be problematic. Subgroup analyses also found no significant differences between groups by respiratory condition or dose (single vs multiple) for these outcomes. Due to extensive variation in dosing within and across studies, we were unable to analyse data or draw further conclusions with respect to dosage or differences between specific molecules. It should be noted that among the eight RCTs 3543465165677189 directly comparing systemic and inhaled routes of corticosteroid administration, none contributed meaningful data for meta-analysis. The decision to initiate corticosteroid and the selection of drug, dose and mode of administration must consider these uncertainties on harms, as well as existing evidence on comparative potency and clinical effectiveness. The riskbenefit rationale is less established for repeated acute use in younger children, such as in recurrent wheezing. ${ }^{114}$

\section{Strengths and limitations}

We conducted a comprehensive systematic review of the literature following rigorous methods, including grey literature, to minimise potential for publication and selection bias. We examined safety outcomes across multiple acute respiratory conditions using 'baskets' of outcomes in each organ system to increase our ability to detect rare events and the precision of our estimates. ${ }^{16}$ This approach is reflective of clinical practice where corticosteroids are used across many respiratory diseases, even if the evidence base is not entirely robust for children. A recent systematic review also assessed the toxicity of short-course oral corticosteroids in children across clinical conditions. ${ }^{115}$ However, there was scarce overlap in respiratory conditions across included studies, and authors mostly provided estimates of the incidence of AEs within treatment groups rather than comparative treatment effects. Studies in adults have also adopted similar approaches to estimate incidence rates of AEs. For example, findings from a recent retrospective cohort in adults showed a significant increase in rates of sepsis, venous thromboembolism and fracture. ${ }^{116}$

This review was limited by the quality of the primary literature, particularly regarding the definition, assessment and reporting of AEs. This underscores the challenges researchers encounter when attempting to synthesise safety data due to sparse and poor reporting, ${ }^{117}$ and highlights the urgent need to enhance detection and reporting of AEs. For example, it is worthwhile noting that 26 studies reported 'no AEs' or 'no significant AE' which could not be included in pooled estimates; this may be a reflection of these studies being under-powered to detect statistically significant findings (especially for rare AEs) and/or AEs that may or may not be considered of special interest and/or clinically important. Such blanket statements are problematic for interpretation, highlighting the need for study authors to clearly report AEs of interest pre-study and post-study conduct. Common nomenclature (eg, www.meddra.org) and standardised approaches to collection of AE data should be implemented to help draw comparisons across studies. Further, safety reporting was not a primary focus of the studies, AEs were rarely defined a priori, and methods for ascertaining AEs were usually absent. While the McHarm scale is recommended to be used in conjunction with other quality assessment tools to evaluate the broader elements of study quality, we used it exclusively to assess methodological quality since the primary focus of this review was on AEs. The AEs reported typically reflect what is detected by a healthcare provider; it is difficult to discern what is reported by patients as well as what patients consider important. The duration of surveillance of most studies was insufficient to detect many of the long-term AEs potentially associated with corticosteroid use. Although the present study suggests that single doses of systemic or inhaled corticosteroids may result in few AEs, recurrent courses may lead to long-term risks, as cumulative dosing has been shown to be a determinant of safety. ${ }^{109}$ Finally, there was variation within and across studies with respect to maintenance corticosteroids, and concomitant and rescue medications. Due to the variation in corticosteroids and 
extensive range of AEs reported (including when a single study contributes to an outcome or in cases of zero events, where meta-analysis was not feasible or meaningful) among varied study designs of overall poor quality, we did not attempt to rate the quality of the body of the evidence using the Grading of Recommendations Assessment, Development and Evaluation ${ }^{118}$ approach.

\section{CONCLUSION}

This is the most comprehensive systematic review to date examining the safety of corticosteroids for managing acute respiratory conditions among young children, an age group of great clinical concern. While the existing evidence suggests that short-term high-dose inhaled or systemic corticosteroids is not associated with an increase in AEs across organ systems, uncertainties remain due to low quality of studies, poor reporting and lack of precision of results. Importantly, these results can help guide future research in the collection and reporting of AEs, particularly concerning measures of growth and behavioural outcomes; this in turn is needed to help inform shared decision-making between clinicians and parents/caregivers of young children.

\section{Author affiliations}

${ }^{1}$ Pediatrics, Hospital de Santa Maria, Lisbon, Portugal

${ }^{2}$ Faculty of Medicine, Instituto de Medicina Molecular, University of Lisbon, Laboratory of Clinical Pharmacology and Therapeutics, Lisbon, Portugal

${ }^{3}$ Alberta Research Centre for Health Evidence, Pediatrics, Faculty of Medicine and Dentistry, University of Alberta, Edmonton, Alberta, Canada

${ }^{4}$ Pediatrics, Faculty of Medicine and Dentistry, University of Alberta, Edmonton, Alberta, Canada

${ }^{5}$ Women \& Children's Health Research Institute, Pediatrics, Faculty of Medicine and Dentistry, University of Alberta, Edmonton, Alberta, Canada

${ }^{6}$ Pediatrics, Faculty of Medicine, University of Ottawa, Ottawa, Ontario, Canada ${ }^{7}$ Pediatrics, Emergency Medicine, and Community Health Sciences, Cumming

School of Medicine, University of Calgary, Calgary, Alberta, Canada

${ }^{8}$ Emergency Medicine, Faculty of Medicine and Dentistry, University of Alberta, Edmonton, Alberta, Canada

${ }^{9}$ School of Public Health, University of Alberta, Edmonton, Alberta, Canada

${ }^{10}$ Pediatrics, Emergency Medicine, and Physiology and Pharmacology, Cumming

School of Medicine, University of Calgary, Calgary, Alberta, Canada

${ }^{11}$ Manitoba Institute of Child Health, Faculty of Medicine, University of Manitoba, Winnipeg, Manitoba, Canada

Acknowledgements We gratefully acknowledge the following individuals for their contributions: Megan Nuspl, Sanjaya Dhakal and Pritam Chordiya for assisting with screening, initial data extraction and verification, and article retrieval; Marc Parsons for assisting with data extraction and verification, and quality assessment; and, Jack Yeung, Marta Oleszczuk and Igor Pravdivyi for assistance with translations. MN, SD, PC and MP received remuneration for their work from a Canadian Institutes of Health Research (CIHR) grant (funding reference number KRS134306). JY, M0 and IP did not receive remuneration for the translation work.

Contributors RMF, AW, BV, SA, ACP, ASS, BHR, DWJ, DA, TPK and LH critically reviewed and contributed to drafts of the report. RF conducted the literature searches. AW conducted screening, quality assessments and data extraction. AW and BV conducted data synthesis/analysis. RMF, AW, BV, SA, ACP, ASS, BHR, DWJ, DA, TPK and LH contributed to interpretation of results. All of the authors approved the final version of this report.

Funding This study was funded by a Knowledge Synthesis Grant from CIHR (funding reference number KRS134306). The funder had no role in the design of the study, the collection, analysis or interpretation of data, the writing of the report or the decision to submit the paper for publication.
Competing interests All authors declare funding from CIHR for the submitted work. LH was funded in part by a New Investigator Salary Award from the CIHR. ACP is supported by a Tier II University of Ottawa Research Chair Award. BHR was supported by a Tier I Canada Research Chair in Evidence-based Emergency Medicine from $\mathrm{CIHR}$. The remaining authors have no financial relationships relevant to this manuscript to disclose. DWJ, TPK and ACP are also authors on some of the included studies.

Patient consent for publication Not required.

Provenance and peer review Not commissioned; externally peer reviewed.

Data sharing statement LH had full access to all of the data in the study and takes responsibility for the integrity of the data and the accuracy of the data analysis. Data for this systematic review (using published data) are available from the corresponding author upon reasonable request.

Open access This is an open access article distributed in accordance with the Creative Commons Attribution Non Commercial (CC BY-NC 4.0) license, which permits others to distribute, remix, adapt, build upon this work non-commercially, and license their derivative works on different terms, provided the original work is properly cited, appropriate credit is given, any changes made indicated, and the use is non-commercial. See: http://creativecommons.org/licenses/by-nc/4.0/.

\section{REFERENCES}

1. de Benedictis FM, Bush A. Corticosteroids in respiratory diseases in children. Am J Respir Crit Care Med 2012;185:12-23.

2. Johnson D. Croup. BMJ Clin Evid 2009;2009.

3. Russell KF, Liang Y, O'Gorman K, et al. Glucocorticoids for croup. Cochrane Database Syst Rev 2011;1:CD001955.

4. Adams NP, Bestall JC, Jones P, et al. Fluticasone at different doses for chronic asthma in adults and children. Cochrane Database Syst Rev 2008:CD003534.

5. Kelly HW, Sternberg AL, Lescher R, et al. Effect of inhaled glucocorticoids in childhood on adult height. $N$ Engl $\mathrm{J}$ Med 2012;367:904-12.

6. van Staa TP, Cooper C, Leufkens HG, et al. Children and the risk of fractures caused by oral corticosteroids. J Bone Miner Res 2003;18:913-8.

7. Castro-Rodriguez JA, Rodrigo GJ. Efficacy of inhaled corticosteroids in infants and preschoolers with recurrent wheezing and asthma: a systematic review with meta-analysis. Pediatrics 2009;123:e519-e525.

8. Zhang L, Axelsson I, Chung M, et al. Dose response of inhaled corticosteroids in children with persistent asthma: a systematic review. Pediatrics 2011;127:129-38.

9. Loke YK, Price D, Herxheimer A. Systematic reviews of adverse effects: framework for a structured approach. BMC Med Res Methodol 2007;7:1-9.

10. Singh JA, Wells GA, Christensen R, et al. Adverse effects of biologics: a network meta-analysis and Cochrane overview. Cochrane Database Syst Rev 2011;2:CD008794.

11. Higgins J, Green S. The Cochrane Handbook for Systematic Reviews of Interventions Version 5.1.0. [updated March 2011]. The Cochrane Collaboration. 2011 www.cochrane-handbook.org

12. Moher D, Liberati A, Tetzlaff J, et al. PRISMA Group. Preferred reporting items for systematic reviews and meta-analyses: the PRISMA statement. J Clin Epidemiol 2009;62:1006-12.

13. Zorzela L, Loke YK, loannidis JP, et al. PRISMA harms checklist: improving harms reporting in systematic reviews. BMJ 2016;352:i157.

14. Global Initiative for Asthma. Global strategy for asthma management and prevention. http://www.ginasthma.org (Accessed 12 Jan 2018).

15. Nebeker JR, Barach $P$, Samore MH. Clarifying adverse drug events: a clinician's guide to terminology, documentation, and reporting. Ann Intern Med 2004;140:795-801.

16. Tugwell P, Judd MG, Fries JF, et al. Powering our way to the elusive side effect: a composite outcome 'basket' of predefined designated endpoints in each organ system should be included in all controlled trials. J Clin Epidemiol 2005;58:785-90.

17. Chou R, Aronson N, Atkins DL, et al. Assessing harms when comparing medication interventions. Methods guide for effectiveness and comparative effectiveness reviews. Rockville, MD: Agency for Healthcare Research and Quality (US), 2008.

18. Bradburn MJ, Deeks JJ, Berlin JA, et al. Much ado about nothing: a comparison of the performance of meta-analytical methods with rare events. Stat Med 2007;26:53-77. 
19. Hedges LV. Comment on 'Misunderstandings about $Q$ and "Cochran's Q Test" in meta analysis'. Stat Med 2016;35:496-7.

20. Egger M, Davey Smith G, Schneider M, et al. Bias in meta-analysis detected by a simple, graphical test. BMJ 1997;315:629-34.

21. The Cochrane Collaboration. Review Manager (RevMan) [computer program]. Version 5.3. Copenhagen: The Nordic Cochrane Centre, 2014.

22. TS Inc. TIBCO Spotfire S+ Workbench, Version 3.4 [statistical software], 1996.

23. Alangari AA, Malhis N, Mubasher M, et al. Budesonide nebulization added to systemic prednisolone in the treatment of acute asthma in children: a double-blind, randomized, controlled trial. Chest 2014;145:772-8.

24. Alansari K, Sakran M, Davidson BL, et al. Oral dexamethasone for bronchiolitis: a randomized trial. Pediatrics 2013;132:e810-e816.

25. Aljebab F, Alanazi M, Choonara I, et al. Observational study on the palatability and tolerability of oral prednisolone and oral dexamethasone in children in Saudi Arabia and the UK. Arch Dis Child 2018;103:83-8.

26. Alshehr M, Almegamsi T, Hammdi A. Efficacy of a small dose of oral dexamethasone in croup. Biomed Res 2005;16:65-72.

27. Altamimi S, Robertson G, Jastaniah W, et al. Single-dose oral dexamethasone in the emergency management of children with exacerbations of mild to moderate asthma. Pediatr Emerg Care 2006;22:786-93.

28. Bacharier LB, Phillips BR, Zeiger RS, et al. Episodic use of an inhaled corticosteroid or leukotriene receptor antagonist in preschool children with moderate-to-severe intermittent wheezing. J Allergy Clin Immunol 2008;122:1127-35.

29. Bisgaard H, Hermansen MN, Loland L, et al. Intermittent inhaled corticosteroids in infants with episodic wheezing. N Engl J Med 2006;354:1998-2005.

30. Bjornson CL, Klassen TP, Williamson J, et al. Pediatric emergency research canada network. A randomized trial of a single dose of oral dexamethasone for mild croup. N Engl J Med 2004;351:1306-13.

31. Brunette MG, Lands L, Thibodeau LP. Childhood asthma: prevention of attacks with short-term corticosteroid treatment of upper respiratory tract infection. Pediatrics 1988;81:624-9.

32. Buckingham SC, Jafri HS, Bush AJ, et al. A randomized, doubleblind, placebo-controlled trial of dexamethasone in severe respiratory syncytial virus (RSV) infection: effects on RSV quantity and clinical outcome. J Infect Dis 2002;185:1222-8.

33. Bülow SM, Nir M, Levin E, et al. Prednisolone treatment of respiratory syncytial virus infection: a randomized controlled trial of 147 infants. Pediatrics 1999;104:e77.

34. Chang AB, Clark R, Sloots TP, et al. A 5- versus 3-day course of oral corticosteroids for children with asthma exacerbations who are not hospitalised: a randomised controlled trial. Med J Aust 2008;189:306-10.

35. Chen ZG, Li M, Chen $\mathrm{H}$, et al. [Efficacy of pulmicort suspension plus salbutamol and ipratropium bromide for management of acute asthma exacerbation in children: a comparative study]. Nan Fang Yi Ke Da Xue Xue Bao 2008;28:470-2.

36. Chub-Uppakarn S, Sangsupawanich P. A randomized comparison of dexamethasone $0.15 \mathrm{mg} / \mathrm{kg}$ versus $0.6 \mathrm{mg} / \mathrm{kg}$ for the treatment of moderate to severe croup. Int $J$ Pediatr Otorhinolaryngol 2007;71:473-7.

37. Clavenna A, Sequi M, Cartabia M, et al. Effectiveness of nebulized beclomethasone in preventing viral wheezing: an RCT. Pediatrics 2014;133:e505-12.

38. Connett GJ, Warde C, Wooler E, et al. Prednisolone and salbutamo in the hospital treatment of acute asthma. Arch Dis Child 1994;70:170-3.

39. Connolly JH, Field CM, Glasgow JF, et al. A double blind trial of prednisolone in epidemic bronchiolitis due to respiratory syncytial virus. Acta Paediatr Scand 1969;58:116-20.

40. Corneli HM, Zorc JJ, Mahajan P, et al. A multicenter, randomized, controlled trial of dexamethasone for bronchiolitis. N Engl J Med 2007;357:331-9.

41. Cronin JJ, McCoy S, Kennedy U, et al. A randomized trial of singledose oral dexamethasone versus multidose prednisolone for acute exacerbations of asthma in children who attend the emergency department. Ann Emerg Med 2016;67:593-601.

42. Csonka P, Kaila M, Laippala $\mathrm{P}$, et al. Oral prednisolone in the acute management of children age 6 to 35 months with viral respiratory infection-induced lower airway disease: a randomized, placebocontrolled trial. J Pediatr 2003;143:725-30.

43. Daugbjerg $\mathrm{P}$, Brenøe $\mathrm{E}$, Forchhammer $\mathrm{H}$, et al. A comparison between nebulized terbutaline, nebulized corticosteroid and systemic corticosteroid for acute wheezing in children up to 18 months of age. Acta Paediatr 1993;82:547-51.
44. Dawson KP, Sharpe C. A comparison of the acceptability of prednisolone tablets and prednisolone sodium phosphate solution in childhood acute asthma. Aust J Hosp Pharm 1993;23:320-3.

45. Ducharme FM, Lemire C, Noya FJ, et al. Preemptive use of highdose fluticasone for virus-induced wheezing in young children. $N$ Engl J Med 2009;360:339-53.

46. Eboriadou M, Chryssanthopoulou D, Stamoulis P, et al. The effectiveness of local corticosteroids therapy in the management of mild to moderate viral croup. Minerva Pediatr 2010;62:23-8.

47. Eden AN, Kaufman A, Yu R. Corticosteroids and croup. Controlled double-blind study. JAMA 1967;200:403-4.

48. Escobedo Chavez E, Garcia Muniz LO, Thompson Chagoyan O, et al. Steroids and inhalation therapy in the management of acute asthma in children. Current Therapeutic Research 1992;52:7-12.

49. Fifoot AA, Ting JY. Comparison between single-dose oral prednisolone and oral dexamethasone in the treatment of croup: a randomized, double-blinded clinical trial. Emerg Med Australas 2007;19:51-8

50. Fitzgerald D, Mellis C, Johnson M, et al. Nebulized budesonide is as effective as nebulized adrenaline in moderately severe croup. Pediatrics 1996;97:722-5.

51. Francis P, Geelhoed G, Harris MA, et al. Effect of nebulised fluticasone propionate $1 \mathrm{mg}$ twice daily compared with oral prednisolone in pre-school children aged 48 months or less with an acute exacerbation of asthma [abstract]. Eur Respir J 1997(Suppl 25):275s.

52. Garbutt JMC, Bridget C, Sterkel R, et al. The comparative effectiveness of prednisolone and dexamethasone for children with croup: A community-based randomized trial. Clin Pediatr 2013;52:1014-21.

53. Ghirga G, Ghirga P, Fagioli S, et al. Intermittent treatment with high dose nebulized beclomethasone for recurrent wheezing in infants due to upper respiratory tract infection. Minerva Pediatr 2002;54:217-20.

54. Gill N, Sirizzotti N, Johnson D, et al. Endogenous glucocorticoid response to single-dose dexamethasone for croup in children: a pharmacodynamic study. Pediatr Emerg Care 2017;11:1.

55. Goebel J, Estrada B, Quinonez J, et al. Prednisolone plus albuterol versus albuterol alone in mild to moderate bronchiolitis. Clin Pediatr 2000;39:213-20.

56. Grant CC, Duggan AK, Santosham M, et al. Oral prednisone as a risk factor for infections in children with asthma. Arch Pediatr Adolesc Med 1996;150:58-63.

57. Gries DM, Moffitt DR, Pulos E, et al. A single dose of intramuscularly administered dexamethasone acetate is as effective as oral prednisone to treat asthma exacerbations in young children. $J$ Pediatr 2000;136:298-303.

58. Hedlin G, Svedmyr J, Ryden AC. Systemic effects of a short course of betamethasone compared with high-dose inhaled budesonide in early childhood asthma. Acta Paediatr 1999;88:48-51.

59. Husby S, Agertoft L, Mortensen S, et al. Treatment of croup with nebulised steroid (budesonide): a double blind, placebo controlled study. Arch Dis Child 1993;68:352-5.

60. Inglis AF. Herpes simplex virus infection. A rare cause of prolonged croup. Arch Otolaryngol Head Neck Surg 1993;119:551-2.

61. Jan JS, Wu WF. Acute effect of glucocorticoid treatment on serum osteocalcin levels in asthmatic children. J Microbiol Immunol Infect 2000;33:25-8.

62. Jartti T, Nieminen R, Vuorinen T, et al. Short- and long-term efficacy of prednisolone for first acute rhinovirus-induced wheezing episode. $J$ Allergy Clin Immunol 2015;135:691-8.

63. Jartti T, Lehtinen P, Vanto $\mathrm{T}$, et al. Evaluation of the efficacy of prednisolone in early wheezing induced by rhinovirus or respiratory syncytial virus. Pediatr Infect Dis J 2006;25:482-8.

64. Jartti T, Lehtinen P, Vanto T, et al. Efficacy of prednisolone in children hospitalized for recurrent wheezing. Pediatr Allergy Immunol 2007;18:326-34.

65. Johnson DW, Jacobson S, Edney PC, et al. A comparison of nebulized budesonide, intramuscular dexamethasone, and placebo for moderately severe croup. N Engl J Med 1998;339:498-503.

66. Johnson DW, Schuh S, Koren G, et al. Outpatient treatment of croup with nebulized dexamethasone. Arch Pediatr Adolesc Med 1996;150:349-55.

67. Klassen TP, Craig WR, Moher D, et al. Nebulized budesonide and oral dexamethasone for treatment of croup: a randomized controlled trial. JAMA 1998;279:1629-32.

68. Klassen TP, Feldman ME, Watters LK, et al. Nebulized budesonide for children with mild-to-moderate croup. N Engl J Med 1994;331:285-9. 
69. Klassen TP, Watters LK, Feldman ME, et al. The efficacy of nebulized budesonide in dexamethasone-treated outpatients with croup. Pediatrics 1996;97:463-6.

70. Kuyucu S, Unal S, Kuyucu N, et al. Additive effects of dexamethasone in nebulized salbutamol or L-epinephrine treated infants with acute bronchiolitis. Pediatr Int 2004;46:539-44.

71. Lai ST, Hua YM, Lai YS, et al. Comparison of nebulized budesonide with intravenous dexamethasone in the treatment of young children hospitalized with acute asthma. J Med Sci 2005;25:223-8.

72. Langton Hewer S, Hobbs J, Reid F, et al. Prednisolone in acute childhood asthma: clinical responses to three dosages. Respir Med 1998;92:541-6.

73. Lee KM, Lin YZ, Huang FY. Steroid-induced acute psychosis in a child with asthma: report of one case. Acta Paediatr Taiwan 2001;42:169-71.

74. Leer JA, Green JL, Heimlich EM, et al. A controlled, collaborative study in 297 infants and children. Am J Dis Child 1969;117:495-503.

75. Lehmann $\mathrm{S}$, Ott $\mathrm{H}$. Glucocorticoid hypersensitivity as a rare but potentially fatal side effect of paediatric asthma treatment: a case report. J Med Case Rep 2008;2:186.

76. Leipzig B, Oski FA, Cummings $\mathrm{CW}$, et al. A prospective randomized study to determine the efficacy of steroids in treatment of croup. $J$ Pediatr 1979;94:194-6.

77. Lin YZ, Hsieh KH, Chen W, et al. Clinical trial of corticosteroid and beta-2 bronchodilator in acute wheezing infants. Zhonghua Min Guo Xiao Er Ke Yi Xue Hui Za Zhi 1991;32:333-40.

78. Lucas-Bouwman ME, Roorda RJ, Jansman FG, et al. Crushed prednisolone tablets or oral solution for acute asthma? Arch Dis Child 2001;84:347-8.

79. Nahum A, Garty BZ, Marcus N, et al. Severe hypersensitivity reactions to corticosteroids in children. Pediatr Emerg Care 2009;25:339-41.

80. Paniagua N, Munoz N, Lopez R, et al. Randomized trial of two doses of oral dexamethasone versus prednisone/prednisolone for children with acute asthma exacerbations in pediatric emergency department. Eur J Pediatr Conference: 6th Congress of the European Academy of Paediatric Societies Switzerland 2016;175:1480.

81. Panickar J, Lakhanpaul M, Lambert PC, et al. Oral prednisolone for preschool children with acute virus-induced wheezing. $N$ Engl J Med 2009;360:329-38.

82. Panigada S, Sacco O, Girosi D, et al. Corticosteroids may favor proliferation of thoracic inflammatory myofibroblastic tumors. Pediatr Pulmonol 2014;49:E109-E111.

83. Plint AC, Johnson DW, Patel $\mathrm{H}$, et al. Epinephrine and dexamethasone in children with bronchiolitis. N Engl J Med 2009;360:2079-89.

84. Razi CH, Akelma AZ, Harmanci K, et al. The addition of inhaled budesonide to standard therapy shortens the length of stay in hospital for asthmatic preschool children: a randomized double-blind, placebo-controlled trial. Int Arch Allergy Immunol 2015;166:297-303.

85. Roberts GW, Master VV, Staugas RE, et al. Repeated dose inhaled budesonide versus placebo in the treatment of croup. $J$ Paediatr Child Health 1999;35:170-4.

86. Roorda RJ, Walhof CM. Effects of inhaled fluticasone propionate administered with metered dose inhaler and spacer in mild to moderate croup: a negative preliminary report. Pediatr Pulmonol 1998;25:114-7.

87. Roosevelt G, Sheehan K, Grupp-Phelan J, et al. Dexamethasone in bronchiolitis: a randomised controlled trial. Lancet 1996;348:292-5.

88. Sadowitz PD, Page NE, Crowley K. Adverse effects of steroid therapy in children with pharyngitis with unsuspected malignancy. Pediatr Emerg Care 2012;28:807-9.

89. Saito M, Kikuchi Y, Kawarai Lefor A, et al. High-dose nebulized budesonide is effective for mild asthma exacerbations in children under 3 years of age. Eur Ann Allergy Clin Immunol 2017;49:22-7.

90. Schuh $\mathrm{S}$, Coates AL, Dick P, et al. A single versus multiple doses of dexamethasone in infants wheezing for the first time. Pediatr Pulmonol 2008;43:844-50.

91. Schuh S, Willan AR, Stephens D, et al. Can montelukast shorten prednisolone therapy in children with mild to moderate acute asthma? A randomized controlled trial. J Pediatr 2009;155:795-800.

92. Siomou E, Challa A, Tzoufi M, et al. Biochemical markers of bone metabolism in infants and children under intravenous corticosteroid therapy. Calcif Tissue Int 2003;73:319-25.
93. Sparrow A, Geelhoed G. Prednisolone versus dexamethasone in croup: a randomised equivalence trial. Arch Dis Child 2006;91:580-3.

94. Stafford L, Hope ME, Janney EP, et al. Comparison of paediatric steroid mixtures. The Australian Journal of Hospital Pharmacy 1998;28:246-9.

95. Storr J, Barrell E, Barry W, et al. Effect of a single oral dose of prednisolone in acute childhood asthma. Lancet 1987;1:879-82.

96. Sumboonnanonda A, Suwanjutha S, Sirinavin S. Randomized controlled trial of dexamethasone in infectious croup. $J$ Med Assoc Thai 1997;80:262-5.

97. Sung L, Osmond MH, Klassen TP. Randomized, controlled trial of inhaled budesonide as an adjunct to oral prednisone in acute asthma. Acad Emerg Med 1998;5:209-13.

98. Super DM, Cartelli NA, Brooks LJ, et al. A prospective randomized double-blind study to evaluate the effect of dexamethasone in acute laryngotracheitis. J Pediatr 1989;115:323-9.

99. Sussman S, Grossman M, Magoffin R, et al. Dexamethasone (16-alpha-methyl, 9-alpha-fluoroprednisolone) in obstructive respiratory tract infections in children. a controlled study. Pediatrics 1964;34:851-5.

100. Svedmyr J, Nyberg E, Asbrink-Nilsson E, et al. Intermittent treatment with inhaled steroids for deterioration of asthma due to upper respiratory tract infections. Acta Paediatr 1995;84:884-8.

101. Svedmyr J, Nyberg E, Thunqvist P, et al. Prophylactic intermittent treatment with inhaled corticosteroids of asthma exacerbations due to airway infections in toddlers. Acta Paediatr 1999;88:42-7.

102. Tagarro A, Pérez L, Quintero VM, et al. Dexamethasone does not reduce length of hospitalization or recurrent wheezing 1 year after early bronchiolitis. Minerva Pediatr 2014;66:131-40.

103. Tal A, Bavilski C, Yohai D, et al. Dexamethasone and salbutamo in the treatment of acute wheezing in infants. Pediatrics 1983;71:13-18.

104. Tamura A, Matsubara K, Tanaka T, et al. Methylprednisolone pulse therapy for refractory Mycoplasma pneumoniae pneumonia in children. J Infect 2008;57:223-8.

105. Teeratakulpisarn J, Limwattananon C, Tanupattarachai S, et al. Efficacy of dexamethasone injection for acute bronchiolitis in hospitalized children: a randomized, double-blind, placebocontrolled trial. Pediatr Pulmonol 2007;42:433-9.

106. van Woensel JB, Wolfs TF, van Aalderen WM, et al. Randomised double blind placebo controlled trial of prednisolone in children admitted to hospital with respiratory syncytial virus bronchiolitis Thorax 1997;52:634-7.

107. Webb MS, Henry RL, Milner AD. Oral corticosteroids for wheezing attacks under 18 months. Arch Dis Child 1986;61:15-19.

108. Zhang L, Ferruzzi E, Bonfanti T, et al. Long and short-term effect of prednisolone in hospitalized infants with acute bronchiolitis. $J$ Paediatr Child Health 2003;39:548-51.

109. Kelly HW, Van Natta ML, Covar RA, et al. Effect of long-term corticosteroid use on bone mineral density in children: a prospective longitudinal assessment in the childhood Asthma Management Program (CAMP) study. Pediatrics 2008;122:e53-e61.

110. Fuhlbrigge AL, Kelly HW. Inhaled corticosteroids in children: effects on bone mineral density and growth. Lancet Respir Med 2014:2:487-96.

111. Aljebab F, Choonara I, Conroy S. Systematic Review of the Toxicity of Long-Course Oral Corticosteroids in Children. PLoS One 2017; 12:e0170259.

112. Vatti RR, Ali F, Teuber S, et al. Hypersensitivity reactions to corticosteroids. Clin Rev Allergy Immunol 2014;47:26-37.

113. Rieder M. Size and taste matters: recent progress in the development of age-appropriate medicines for children. Pharmaceut Med 2018;32:21-30.

114. Beigelman A, Durrani S, Guilbert TW. Should a preschool child with acute episodic wheeze be treated with oral corticosteroids? A Pro/ Con Debate. J Allergy Clin Immunol Pract 2016;4:27-35.

115. Aljebab F, Choonara I, Conroy S. Systematic review of the toxicity of short-course oral corticosteroids in children. Arch Dis Child 2016;101:365-70.

116. Waljee AK, Rogers MA, Lin P, et al. Short term use of oral corticosteroids and related harms among adults in the United States: population based cohort study. BMJ 2017;357:j1415.

117. Hartling L, Ali S, Dryden DM, et al. How safe are common analgesics for the treatment of acute pain for children? a systematic review. Pain Res Manag 2016;2016:1-15.

118. Guyatt GH, Oxman AD, Vist GE, et al. GRADE: an emerging consensus on rating quality of evidence and strength of recommendations. BMJ 2008;336:924-6. 